Article

\title{
Capability of Immobilized Clostridium beijerinckii TISTR 1461 on Lotus Stalk Pieces to Produce Butanol from Sugarcane Molasses
}

\author{
Patthranit Narueworanon ${ }^{1}$, Lakkana Laopaiboon ${ }^{2,3}$ and Pattana Laopaiboon ${ }^{2,4, *}$ \\ 1 Graduate School, Khon Kaen University, Khon Kaen 40002, Thailand; patthranit.sa@kkumail.com \\ 2 Department of Biotechnology, Faculty of Technology, Khon Kaen University, Khon Kaen 40002, Thailand; \\ lakcha@kku.ac.th \\ 3 Fermentation Research Center for Value Added Agricultural Products (FerVAAP), \\ Khon Kaen 40002, Thailand \\ 4 Center for Alternative Energy Research and Development, Khon Kaen University, Khon Kaen 40002, Thailand \\ * Correspondence: patlao@kku.ac.th; Tel.: +66-04-336-2121
}

Citation: Narueworanon, P. Laopaiboon, L.; Laopaiboon, P. Capability of Immobilized Clostridium beijerinckii TISTR 1461 on Lotus Stalk Pieces to Produce Butanol from Sugarcane Molasses. Processes 2021, 9 , 573. https://doi.org/10.3390/ pr9040573

Academic Editor: Aydin Berenjian

Received: 27 February 2021

Accepted: 20 March 2021

Published: 25 March 2021

Publisher's Note: MDPI stays neutral with regard to jurisdictional claims in published maps and institutional affiliations.

Copyright: (c) 2021 by the authors. Licensee MDPI, Basel, Switzerland. This article is an open access article distributed under the terms and conditions of the Creative Commons Attribution (CC BY) license (https:// creativecommons.org/licenses/by/ $4.0 /)$.

\begin{abstract}
Immobilized Clostridium beijerinckii TISTR 1461 was used to enhance the butanol production efficiency from sugarcane molasses. Lotus stalk (LS) pieces were used as carriers for cell immobilization. Sugarcane molasses containing $50 \mathrm{~g} / \mathrm{L}$ of sugar supplemented with $1 \mathrm{~g} / \mathrm{L}$ of yeast extract was found to be an appropriate medium for bacterial cell immobilization on the LS pieces. Carrier size (4, 12 and $20 \mathrm{~mm}$ in length) and carrier loading (1:15, 1:30 and 1:45,w/v) were optimized for high levels of butanol production using response surface methodology (RSM). The batch fermentation was carried out under anaerobic conditions in $1 \mathrm{~L}$ screw-capped bottles at $37^{\circ} \mathrm{C}$ and an agitation rate of $150 \mathrm{rpm}$. It was found that the optimum conditions for the butanol production were the carrier size of $4 \mathrm{~mm}$ and carrier loading of 1:31 $(w / v)$. Under these conditions, the butanol concentration $\left(P_{B}\right)$ was $12.89 \mathrm{~g} / \mathrm{L}$, corresponding to the butanol productivity $\left(Q_{B}\right)$ of $0.36 \mathrm{~g} / \mathrm{L} \cdot \mathrm{h}$ and butanol yield $\left(Y_{B / S}\right)$ of $0.36 \mathrm{~g} / \mathrm{g}$. These values were higher than those using free cells $\left(P_{B}, 10.20 \mathrm{~g} / \mathrm{L}, Q_{B}, 0.28 \mathrm{~g} / \mathrm{L} \cdot \mathrm{h}\right.$ and $\left.Y_{B / S}, 0.32 \mathrm{~g} / \mathrm{g}\right)$. In addition, it was found that a $24 \mathrm{~h}$ incubation time for cell immobilization was appropriate for the immobilization process, which was confirmed by the results of the scanning electron microscope (SEM) and atomic force microscopy (AFM) images and specific surface area measurement. When the fermentation using the immobilized cells was carried out in a stirred-tank reactor (STR), column reactor (CR) and CR coupled with STR, the results showed that all reactors could be used to produce butanol production from the immobilized cells on LS pieces. However, the $P_{B}$ using CR and CR coupled with STR were only $75 \%$ and $45 \%$ of those using the screw-capped bottle and STR.
\end{abstract}

Keywords: butanol; ABE fermentation; sugarcane molasses; Clostridium beijerinckii; cell immobilization

\section{Introduction}

Butanol is an industrially useful chemical. It is employed as a solvent in the production of plastics, polymers, lubricants, hydraulic fluids, hormones, drugs, antibiotics, cosmetics and vitamins [1]. It is also a potential renewable biofuel and fuel additive for use in internal combustion engines. Butanol has several advantages. These include a greater energy content along with lower volatility, hydroscopicity, corrosivity and flammability than ethanol [2]. Additionally, butanol can serve as a fuel in gasoline engines with no engine modifications necessary. Thus, it is considered an exciting alternative to first generation biofuels that can also serve as a starting material to make a wide variety of bio-based products [3].

Butanol can be produced by a fermentation process known as acetone-butanol-ethanol (ABE) fermentation. The main microorganisms involving in the ABE fermentation are 
several Clostridium species, including C. acetobutylicum, C. beijerinckii, C. aurantibutyricum, C. carboxidivorans, C. candaveris, C. pasteurianum, C. sporogenes, C. tetanomorphum, C. saccharobutylicum, and C. saccharoperbutylacetonicum $[1,4]$. The ABE fermentation is a two-phase process. The first phase is an acidogenic phase, in which acetic and butyric acids are produced inside the cells with concomitant release into the environment. This is followed by reassimilation of the acids into the cells and their conversion into acetone, butanol and ethanol in a solventogenic phase [5]. In general, solvent toxicity occurs in ABE fermentations, resulting in low butanol titer and productivity. One technique to reduce product inhibition in ABE fermentation is in situ product recovery-e.g., a pervaporation and gas stripping system [6-8].

Apart from in situ product recovery, cell immobilization is one of the techniques that can be applied to increase the robustness of Clostridia and to improve the productivity of solvents as well as to reduce the negative impacts of metabolite accumulation in the ABE fermentation, especially butanol toxicity [9]. A variety of materials for cell immobilization in ABE fermentations have been investigated as potential cell carriers. The primary considerations are economics, as well as suitably high porosity and specific surface area [10]. Materials with a great degree of porosity are necessary for successful ABE fermentations. Additionally, the methods used to accomplish cell immobilization are critical. Previous studies have shown that techniques employing adsorption are frequently used since they are more facile and require no chemicals, providing a more favorable environment for bacterial cells [11]. A variety of materials have been used as carriers or supporters for cell immobilization in ABE fermentation. These include bricks [12,13], zeolite [13], wood pulp [14], corn stalk bagasse [6], sweet sorghum bagasse [9,15] and sugarcane bagasse [9]. In the current study, lotus stalks (LS) were chosen as carriers for bacterial cell immobilization because of their low cost and wide availability as an agro-waste in Thailand. Additionally, their high porosity promotes bacterial adhesion to their surfaces. To the best of our knowledge, there is no report of LS utilization as a carrier for cell immobilization to produce butanol.

Typically, a stirred-tank reactor (STR) is used for butanol production by free cells of Clostridium spp. This is because mixing, mass transfer and heat transfer are easily attained by mechanical agitation with impellers and baffles. However, the costs of an STR are relatively high, and the necessary mechanical agitation requires high energy inputs that may cause cell damage and leakage from the carriers in the case of immobilized cells. Thus, to mitigate these disadvantages, a column reactor (CR) was applied for butanol production by immobilized cells in this study. The advantages of a CR include its low energy requirements, low capital costs, and simple construction [16,17], as well as lower shear during operation, which may protect the immobilized cells in the carriers. Both the STR and CR were applied for butanol production by immobilized cells in this study.

Many agricultural raw materials can be used as substrates for ABE fermentations. Sugarcane molasses is a byproduct of industrial sugar production. It consists of $\sim 60 \%(w / v)$ total soluble sugars, nitrogenous compounds and many trace elements [7]. In Thailand, approximately five million metric tons of sugarcane molasses are produced annually [18]. Sugarcane molasses has potential for use as a substrate to produce numerous important industrial chemicals, such as hydrogen [19], lactic acid [20], sorbitol [21], gluconic acid [22], succinic acid [23], ornithine [24] and butanol [7,8,25,26].

The aims of the current study are to improve butanol production from sugarcane molasses using immobilized C. beijerinckii TISTR 1461. LS pieces were employed as carriers for bacterial cell immobilization. The size and loading of LS pieces in batch butanol fermentation were optimized, and the incubation time for cell immobilization was determined. The LS pieces before and after cell immobilization were characterized. Productivity of batch butanol production by the immobilized cells using an STR, CR and CR coupled with STR was also compared. 


\section{Materials and Methods}

\subsection{Raw Materials}

Sugarcane molasses was provided by Mit Phu Viang Sugar Factory, Nong Rua, Khon Kaen, Thailand. The molasses $\left(\sim 79^{\circ} \mathrm{Bx}\right.$ of total soluble solids) consists of sucrose $(364.46 \mathrm{~g} / \mathrm{L})$, glucose $(103.69 \mathrm{~g} / \mathrm{L})$, fructose $(123.99 \mathrm{~g} / \mathrm{L})$, protein $(6.40 \mathrm{~g} / 100 \mathrm{~mL})$, sulfur $(1036.00 \mathrm{mg} / \mathrm{L})$, phosphorus $(694.17 \mathrm{mg} / \mathrm{L})$, potassium $(33,540.70 \mathrm{mg} / \mathrm{L})$, sodium (574.49 mg/L), calcium (12,085.36 mg/L), magnesium (5733.75 mg/L), iron (152.44 mg/L), manganese (108.99 mg/L), copper (1.54 mg/L) and zinc (1.13 mg/L) [26].

In the current study, yeast extract (YE, Oxoid, UK) and dried spent yeast (DSY) were used as nitrogen sources for butanol production. DSY, a byproduct of the brewing industry, was donated by Beer Thip Brewery Co., Ltd., Phra Nakhon Si Ayutthaya, Thailand. The proximate chemical composition of YE is (\% dry weight) protein (74.50\% dry weight), total carbohydrate $(8.98 \%$ dry weight), total fat $(0.07 \%$ dry weight) and ash $(11.26 \%$ dry weight). DSY consists of (\% dry weight) protein (48.69\% dry weight), total carbohydrate $(36.67 \%$ dry weight), total fat $(2.94 \%$ dry weight), crude fiber $(0.35 \%$ dry weight $)$ and ash $(6.16 \%$ dry weight) [26].

The butanol production medium was prepared by diluting the molasses to obtain a solution with $50 \mathrm{~g} / \mathrm{L}$ of total sugar. Then, $6 \mathrm{~g} / \mathrm{L}$ of DSY was added to the medium before sterilization (modified from the work of Narueworanon et al. [26]). The initial pH value of the sterile butanol production medium was adjusted to 6.5 before use [7].

\subsection{Microorganism and Growth Condition}

C. beijerinckii TISTR 1461 was obtained from the Thailand Institute of Scientific and Technological Research (TISTR). The culture was maintained as spore suspension and kept at $4{ }^{\circ} \mathrm{C}$. The medium for spore activation consisted of $1 \mathrm{~g}$ of cooked meat medium (CMM) and $0.08 \mathrm{~g}$ glucose. It was prepared and anaerobic conditions were created as described by Narueworanon et al. [26]. The spore suspension $\left(\sim 1 \times 10^{6}\right.$ spores $\left./ \mathrm{mL}\right)$ was heat shocked at $80{ }^{\circ} \mathrm{C}$ for $1 \mathrm{~min}$ and then immediately cooled in ice water for $1 \mathrm{~min}$ [27]. The cultures were grown in the sterile CMM at $37{ }^{\circ} \mathrm{C}$ for $9-10 \mathrm{~h}$. The vegetative cells $(5 \%, v / v)$ were grown into a sterile tryptone-glucose-yeast extract (TGY) medium [28] at $37^{\circ} \mathrm{C}$ for $3-4 \mathrm{~h}$ $\left(\mathrm{OD}_{600} \sim 0.5\right)$. Then, it was used as an inoculum $(5 \%, v / v)$ for cell immobilization.

\subsection{Experiments}

\subsubsection{Cell Immobilization on Carriers in Various Media for Batch Butanol Fermentation}

The LS pieces with diameters in the range of 7-10 $\mathrm{mm}$ were cut with a sharp blade into $12 \mathrm{~mm}$ lengths, and were washed and dried at $90^{\circ} \mathrm{C}$ overnight (modified from work of Ariyajaroenwong et al. [29] and Loyarkat et al. [30]). After autoclaving at $110^{\circ} \mathrm{C}$ for $28 \mathrm{~min}$, cultures were added into two sterile immobilization media with a carrier loading of 1:30 $(w / v)$. These two immobilization media were TGY medium and sugarcane molasses medium containing $50 \mathrm{~g} / \mathrm{L}$ of total sugar and $1 \mathrm{~g} / \mathrm{L}$ of YE. The sterile immobilization medium containing LS pieces was purged with OFN gas to obtain anaerobic conditions. After that, $5 \%(v / v)$ of active cells in the TGY medium (Section 2.2) was inoculated into the immobilization medium and incubated at $37{ }^{\circ} \mathrm{C}$ under static conditions for $24 \mathrm{~h}$. Then, the immobilization medium was drained, and the LS pieces were washed with sterile fresh butanol production medium before use in butanol fermentation.

\subsubsection{Butanol Fermentation by Immobilized C. beijerinckii TISTR 1461}

The sterile butanol production medium was sparged with OFN. Then, $600 \mathrm{~mL}$ of the medium was added into $1 \mathrm{~L}$ screw-capped bottles containing immobilized cells on LS pieces (Section 2.3.1) to start the fermentation under anaerobic conditions. The fermentation was performed at $37^{\circ} \mathrm{C}$ with an agitation rate of $150 \mathrm{rpm}$. Samples were taken at set time intervals for analyses. 
Batch fermentation using free cells was also carried out as a control treatment. Highly motile $C$. beijerinckii TISTR 1461 cells in the TGY medium were inoculated in the sterile butanol production medium to start the fermentation under the above conditions.

\subsubsection{Optimization of Size and Loading of LS Pieces for Cell Immobilization to} Produce Butanol

To maximize butanol production efficiency by the immobilized cells, two main factors were optimized-carrier size and carrier loading. The carrier size was varied over the range of 4 to $20 \mathrm{~mm}$, while the carrier loading was carried out in the range of 1:15 to 1:45 $(w / v)$. To optimize the two independent variables for butanol production, response surface methodology (RSM) based on central composite design (CCD) was applied. Each variable was varied at three levels: carrier size $\left(x_{1}: 4,12\right.$ and $\left.20 \mathrm{~mm}\right)$ and carrier loading $\left(x_{2}: 1: 15\right.$, 1:30 and 1:45 w/v). Thirteen experiments were carried out to maximize butanol production (Table 1). Each batch experiment was carried out in triplicate as described in Section 2.3.2. The results are expressed as their mean \pm SD. Experimental design, data analysis, and quadratic model were developed using Design-Expert software (Version 7.0, Stat-Ease, Inc., Minneapolis, MN, USA).

Table 1. The values of variables or factors (size and loading of the carriers) of 13 experimental runs and the response $\left(P_{B}\right)$ of batch butanol fermentation by the immobilized cells using response surface methodology (RSM).

\begin{tabular}{cccc}
\hline Run & $\boldsymbol{x}_{\mathbf{1}}$ : Carrier Size $(\mathbf{m m})$ & $\boldsymbol{x}_{\mathbf{2}}$ : Carrier Loading $(\boldsymbol{w} / \boldsymbol{v})$ & Response: $\boldsymbol{P}_{\boldsymbol{B}}(\mathrm{g} / \mathrm{L})$ \\
\hline 1 & 4 & $1: 15$ & $12.79 \pm 0.12$ \\
2 & 4 & $1: 30$ & $12.96 \pm 0.10$ \\
3 & 4 & $1: 45$ & $12.86 \pm 0.09$ \\
4 & 12 & $1: 15$ & $11.50 \pm 0.30$ \\
5 & 12 & $1: 30$ & $12.03 \pm 0.24$ \\
6 & 12 & $1: 45$ & $11.56 \pm 0.13$ \\
7 & 20 & $1: 15$ & $11.05 \pm 0.28$ \\
8 & 20 & $1: 30$ & $11.41 \pm 0.18$ \\
9 & 20 & $1: 45$ & $11.12 \pm 0.15$ \\
10 & 12 & $1: 30$ & $12.10 \pm 0.22$ \\
11 & 12 & $1: 30$ & $11.82 \pm 0.17$ \\
12 & 12 & $1: 30$ & $12.14 \pm 0.10$ \\
13 & 12 & $1: 30$ & $11.68 \pm 0.14$ \\
\hline
\end{tabular}

The second order model used to simulate the experimental data is given as follows:

$$
Y_{i}=\beta_{0}+\Sigma \beta_{i} x_{i}+\Sigma \beta_{i i} x_{i}^{2}+\Sigma \beta_{i j} x_{i} x_{j}
$$

where $Y_{i}$ is the predicted response; $x_{i}, x_{j}$ are the independent variables that impact the dependent variable, $Y ; \beta_{0}$ is an offset term. The $\beta_{i}$ values are the $i$ th linear coefficients. $\beta_{i i}$ are the $i$ th quadratic coefficients while $\beta_{i j}$ are the $i j$ th interaction coefficients. Analysis of variance (ANOVA) was used for the statistical analysis.

To confirm the reliability of the statistical analysis, a verification experiment was conducted using the predicted optimal carrier size and carrier loading for maximal butanol concentration $\left(P_{B}\right)$ from the RSM analysis results.

\subsubsection{Incubation Time of Cell Immobilization on LS Pieces for Butanol Fermentation}

The incubation time for cell immobilization under the optimal size and loading of LS pieces from Section 2.3.3 in the immobilization medium were varied for 12, 18 and $24 \mathrm{~h}$. After incubation in the immobilization medium, the immobilized cells were used for butanol production as previously described. 


\subsubsection{Butanol Production Using an STR, CR and CR Coupled with an STR}

Immobilized C. beijerinckii TISTR 1461 cells on LS pieces were prepared. Batch butanol fermentation by the immobilized cells at the optimal size and loading of LS pieces was carried out in three bioreactor systems-i.e., an STR, CR or packed-bed bioreactor and a CR coupled with an STR. The STR system consisted of an STR (Biostat ${ }^{\circledR} M$, B. Braun Biotech, Melsungen, Germany) containing 1.2 L of sterile butanol production medium and the LS pieces with an agitation rate of $150 \mathrm{rpm}$. In the CR system with a working volume of $600 \mathrm{~mL}$ (Figure 1a), sterile butanol production medium was fed into the reactor containing sterile LS pieces at the optimal size and loading. The gases $\left(\mathrm{H}_{2}\right.$ and $\left.\mathrm{CO}_{2}\right)$ over the medium were circulated into the bottom of the $\mathrm{CR}$ using a peristaltic pump at a flow rate of $0.5 \mathrm{~L} / \mathrm{min}$ (modified from Bai et al. [31]). In the last system, a CR coupled with an STR (Figure 1b) consisted of an STR containing 1.2 $\mathrm{L}$ of sterile butanol production medium and a CR containing sterile LS pieces at the optimum size and loading. The medium moving between the STR and CR was circulated using a peristaltic pump at a flow rate of $0.5 \mathrm{~L} / \mathrm{min}$. Samples were withdrawn from the three systems at regular time intervals for analyses. In the CR system, samples were removed at the bottom of the CR, whereas in the other two systems, they were taken from a harvesting tube attached to the top plate of the STR.
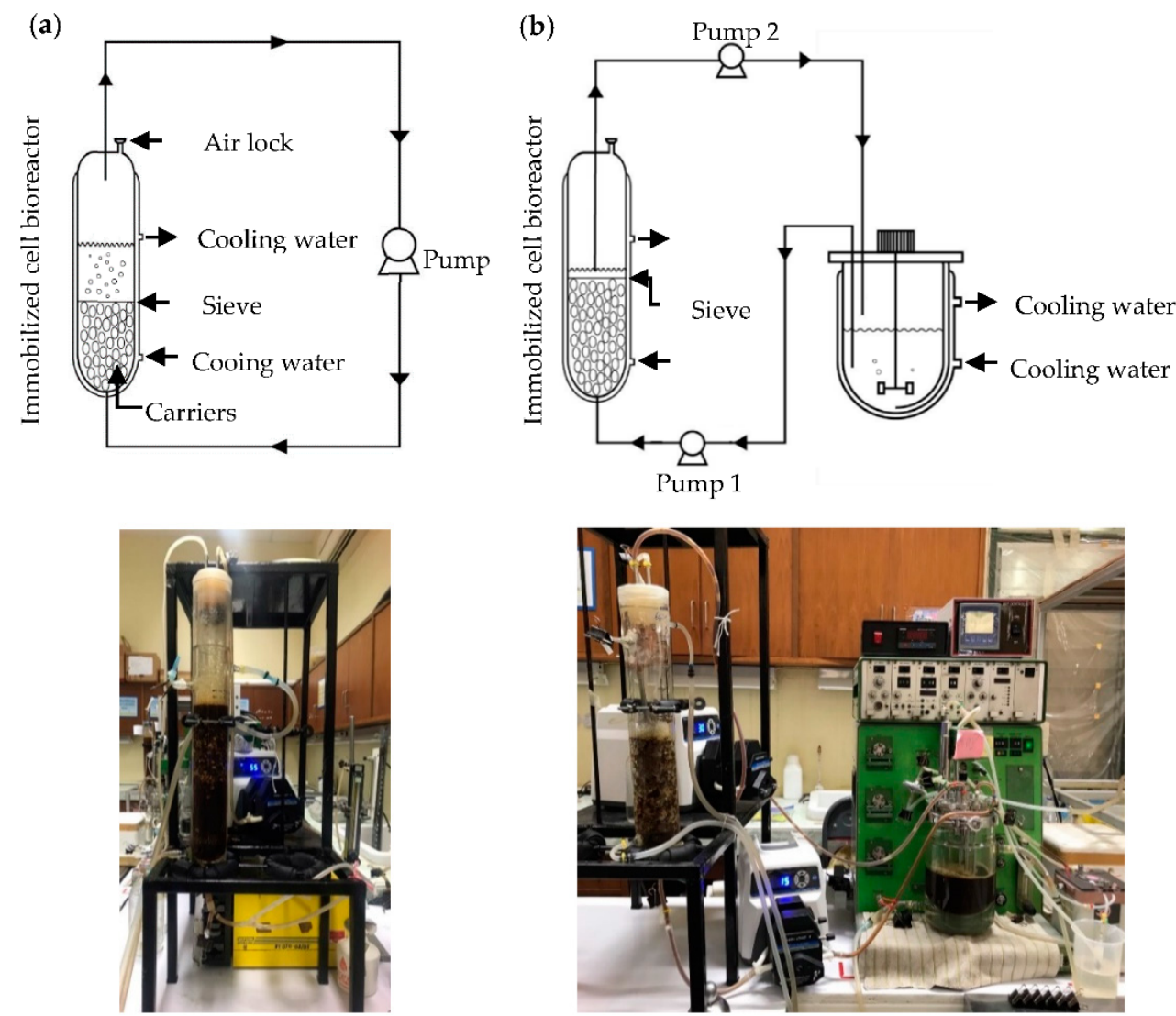

Figure 1. Experimental setup of butanol production from sugarcane molasses by immobilized $C$. beijerinckii TISTR 1461 cells using (a) column reactor (CR) and (b) CR coupled with a stirred-tank reactor (STR).

\subsection{Analytical Methods}

Sugars (sucrose, fructose and glucose) in the sugarcane molasses were analyzed using HPLC with a refractive index (RI) detector (Shimadzu, Japan) using a Pinnacle II column $\left(250 \times 4.6 \mathrm{~mm}\right.$, Restek, Bellefonte, PA, USA). The analysis was carried out at $40{ }^{\circ} \mathrm{C}$ using acetonitrile/water $(75 / 25, v / v)$ as a mobile phase at $0.6 \mathrm{~mL} / \mathrm{min}$ [7]. Solvents and 
acids were measured using gas chromatography (GC) (Shimadzu, GC-2014, Kyoto, Japan) in conjunction with a flame ionization detector (FID) using $\mathrm{H}_{2}$ as a fuel gas. The $\mathrm{ABE}$ fermentation products were separated using a Porapak $Q$ column $(3 \mathrm{~m} \times 2 \mathrm{~mm})$. Oven temperature was programmed to remain constant at $160{ }^{\circ} \mathrm{C}$ for $9 \mathrm{~min}$, then increased from 160 to $220^{\circ} \mathrm{C}$ at a ramp-up rate of $8^{\circ} \mathrm{C} / \mathrm{min}$. Finally, it was held at $220^{\circ} \mathrm{C}$ for $12 \mathrm{~min}$. Injector and detector temperatures were controlled at 220 and $230^{\circ} \mathrm{C}$, respectively. The carrier gas was $\mathrm{N}_{2}$ and the internal standard was isobutanol [27]. Total sugar concentrations were measured using a standard phenol-sulfuric acid method [32]. The cell concentration in the inoculum was measured using a spectrophotometer at an optical density of $600 \mathrm{~nm}$ [27]. The butanol yield $\left(Y_{B / S}, \mathrm{~g} / \mathrm{g}\right)$ was calculated as the butanol produced $(\mathrm{g} / \mathrm{L})$ divided by the sugar utilized $(\mathrm{g} / \mathrm{L})$. The butanol productivity $\left(Q_{B}, \mathrm{~g} / \mathrm{L} \cdot \mathrm{h}\right)$ and $A B E$ productivity $\left(Q_{A B E}\right.$, $\mathrm{g} / \mathrm{L} \cdot \mathrm{h})$ were calculated as the butanol or $\mathrm{ABE}$ produced $(\mathrm{g} / \mathrm{L})$ divided by the fermentation time (h) [26].

LS pieces before and after cell immobilization were characterized using scanning electron microscopy (SEM). The LS pieces were dried at $90{ }^{\circ} \mathrm{C}$ until a constant weight was achieved. The dried LS pieces were cut and coated with a $2 \mu \mathrm{m}$ thick layer of gold under a pressure of 1 mbar for 15 min before observation under a SEM (HitachiS-3000N) (Tokyo, Japan). Surface structures of the LS pieces were characterized using atomic force microscopy (AFM) (XE-100, Pottstown, PA, USA). The specific surface area measurements of LS pieces before and after cell immobilization were carried out using a Brunauer-EmmettTeller (BET) surface area method (Bel Sorp mini II, BEL, Osaka, Japan). BET surface areas and pore volumes were obtained from $\mathrm{N}_{2}$ adsorption/desorption curves using Belsorp Adsorption/Desorption Data Analysis Software Ver. 6.1.0.4.

\section{Results and Discussion}

\subsection{Low-Cost Medium for Cell Immobilization in Batch Butanol Fermentation}

To determine a low-cost medium for cell immobilization, TGY medium (control medium) and sugarcane molasses medium, containing $50 \mathrm{~g} / \mathrm{L}$ of total sugar and $1 \mathrm{~g} / \mathrm{L}$ of YE, were used for cell immobilization. After $24 \mathrm{~h}$ incubation in these media, the immobilized cells were used for butanol fermentation from the butanol production medium. The results showed that the batch profiles of ABE fermentation by the immobilized cells in TGY medium were similar to those in the sugarcane molasses medium (Figure 2). The $\mathrm{pH}$ of the fermentation broth decreased sharply during the $12 \mathrm{~h}$ fermentation, corresponding to acetic and butyric acid production (Figure $2 b$ ). This indicated that acidogenesis occurred in this period, implying that cells were very active. $\mathrm{pH}$ in the fermentation broth slightly increased after $12 \mathrm{~h}$, and acetone, butanol and ethanol were detected (Figure 2a), indicating the occurrence of solventogenesis. It was reported that $\mathrm{pH}$ had a significant effect on bacterial growth as well as butanol yield and productivity [33]. In this study, the initial $\mathrm{pH}$ of the fermentation broth was set at 6.5, the optimum value for butanol production from sugarcane molasses by C. beijerinckii TISTR 1461 [7]. Controlled pH did not promote butanol production [33]. Therefore, in the current study, the $\mathrm{pH}$ of the broth was not controlled during the fermentation. During fermentation, the sugar level decreased from 50 to $\sim 17 \mathrm{~g} / \mathrm{L}$. The remaining sugar in the fermentation broth indicated that NADH produced in prepyruvate metabolism was sufficient for butanol production via postpyruvate metabolism. However, $C$. beijerinckii TISTR 1461 could not completely utilize these sugars. This might have been due to butanol toxicity. At $36 \mathrm{~h}$ of fermentation, the $P_{B}$ values presented by the immobilized cells in TGY and sugarcane molasses media were not significantly different, as shown in Table 2. Additionally, other parameters measured during butanol fermentation were not significantly different, indicating that sugarcane molasses added with $1 \mathrm{~g} / \mathrm{L}$ of YE could be used as a low-cost immobilization medium for butanol fermentation. TGY was not suitable for use as a cell immobilization medium for a large scale operation due to its high cost. Thus, sugarcane molasses medium added with $1 \mathrm{~g} / \mathrm{L}$ of YE was used as the medium for cell immobilization in the following experiments. 

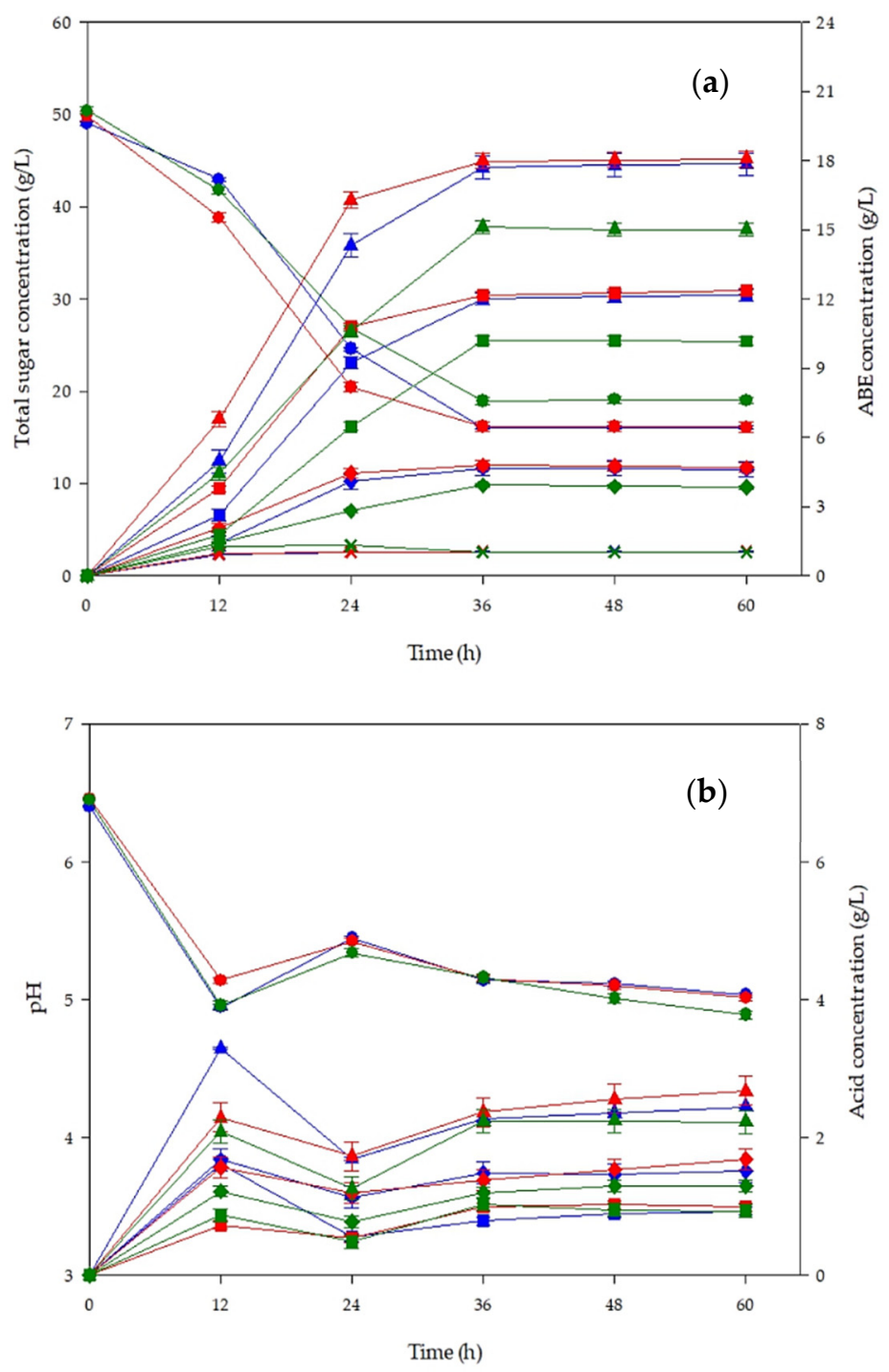

Figure 2. Butanol production profiles from sugarcane molasses by immobilized C. beijerinckii TISTR 1461 cells on lotus stalk (LS) pieces in tryptone-glucose-yeast extract (TGY) medium (blue lines) and sugarcane molasses medium (red lines) and by free cells (green lines): (a) total sugar $(\bullet)$, acetone $(\bullet)$, butanol $(\boldsymbol{\square})$, ethanol $(\mathrm{x})$, acetone-butanol-ethanol (ABE) $(\boldsymbol{\Delta})$ and $(\mathbf{b}) \mathrm{pH}(\bigcirc)$, acetic acid $(\diamond)$, butyric acid $(\square)$ and total acids $(\Delta)$.

When the batch butanol fermentation using free cells of $C$. beijerinckii TISTR 1461 was carried out as a control experiment, the results showed that the batch profiles of the ABE fermentation using free cells were similar to those utilizing immobilized cells (Figure 2). However, at $36 \mathrm{~h}$ of fermentation, the sugar consumption $(31.48 \mathrm{~g} / \mathrm{L})$, maximum total $\operatorname{ABE}\left(P_{A B E}, 15.23 \mathrm{~g} / \mathrm{L}\right)$ and $P_{B}(10.20 \mathrm{~g} / \mathrm{L})$ using free cells were lower than those using immobilized cells (Table 2). Additionally, it was found that butanol yield $\left(Y_{B / S}\right)$ using free cells was lower than when employing immobilized cells (Table 2). A high $Y_{B / S}$ was observed in this study when compared to other reports, in which the reported $Y_{B / S}$ values were only 0.22 to $0.28 \mathrm{~g} / \mathrm{g}$ [34-36]. 
Table 2. ABE fermentation from sugarcane molasses (50 g/L of sugar) supplemented with dried spent yeast (DSY) by immobilized cells of $C$. beijerinckii TISTR 1461 in various media and by free cells (control experiment) at $36 \mathrm{~h}$ of fermentation.

\begin{tabular}{cccc}
\hline \multirow{2}{*}{ Parameter } & \multicolumn{2}{c}{ Immobilized Cells in } & Free Cells \\
\cline { 2 - 4 } & TGY Medium & Sugarcane Molasses Medium \\
\hline Acetone (g/L) & $4.67 \pm 0.32^{\mathrm{a}}$ & $4.78 \pm 0.20^{\mathrm{a}}$ & $3.92 \pm 0.07^{\mathrm{b}}$ \\
Butanol (g/L) & $12.01 \pm 0.25^{\mathrm{a}}$ & $12.17 \pm 0.13^{\mathrm{a}}$ & $10.20 \pm 0.17^{\mathrm{b}}$ \\
Ethanol (g/L) & $1.03 \pm 0.02^{\mathrm{a}}$ & $1.03 \pm 0.01^{\mathrm{a}}$ & $1.01 \pm 0.01^{\mathrm{a}}$ \\
ABE (g/L) & $17.71 \pm 0.50^{\mathrm{a}}$ & $17.98 \pm 0.34^{\mathrm{a}}$ & $15.13 \pm 0.25^{\mathrm{b}}$ \\
Acetic acid (g/L) & $1.49 \pm 0.16^{\mathrm{a}}$ & $1.38 \pm 0.15^{\mathrm{a}}$ & $1.29 \pm 0.08^{\mathrm{a}}$ \\
Butyric acid (g/L) & $0.79 \pm 0.06^{\mathrm{a}}$ & $0.99 \pm 0.06^{\mathrm{a}}$ & $1.16 \pm 0.09^{\mathrm{b}}$ \\
Total acids (g/L) & $2.28 \pm 0.22^{\mathrm{a}}$ & $2.37 \pm 0.20^{\mathrm{a}}$ & $2.45 \pm 0.17^{\mathrm{a}}$ \\
Sugar utilized (g/L) & $32.95 \pm 0.20^{\mathrm{a}}$ & $33.67 \pm 0.53^{\mathrm{a}}$ & $31.48 \pm 0.37^{\mathrm{b}}$ \\
$Y_{B / S}(\mathrm{~g} / \mathrm{g})$ & $0.36 \pm 0.00^{\mathrm{a}}$ & $0.36 \pm 0.01^{\mathrm{a}}$ & $0.32 \pm 0.01^{\mathrm{b}}$ \\
$Q_{B}(\mathrm{~g} / \mathrm{L} \cdot \mathrm{h})$ & $0.32 \pm 0.01^{\mathrm{a}}$ & $0.33 \pm 0.01^{\mathrm{a}}$ & $0.28 \pm 0.01^{\mathrm{b}}$ \\
$Q_{A B E}(\mathrm{~g} / \mathrm{L} \cdot \mathrm{h})$ & $0.49 \pm 0.01^{\mathrm{a}}$ & $0.50 \pm 0.01^{\mathrm{a}}$ & $0.42 \pm 0.01^{\mathrm{b}}$ \\
\hline
\end{tabular}

The experiments were performed in triplicate and the results are expressed as mean \pm SD. ${ }^{\mathrm{a}, \mathrm{b}}$ Means followed by the same letter within the same row are not significantly different using Duncan's multiple range test at the level of $\alpha=0.05$. $Y_{B / S}$, butanol yield; $Q_{B}$, butanol productivity and $Q_{A B E}, \mathrm{ABE}$ productivity.

\subsection{Optimal Size and Loading of LS Pieces for Cell Immobilization to Produce Butanol}

C. beijerinckii TISTR 1461 cells immobilized on LS pieces at various carrier sizes and loadings, as shown in Table 1, were used for butanol fermentation. The batch butanol fermentation profiles of the 13 experimental runs were similar to those in Figure 2 (data not shown). The response or $P_{B}$ values of the 13 experimental runs, including five replicates (Runs 5, 10-13) of the central point, are shown in Table 1 . The $P_{B}$ values ranged from 11.05 (Run 7) to $12.96 \mathrm{~g} / \mathrm{L}$ (Run 2). These data were used to derive a quadratic polynomial to predict butanol levels in ABE fermentations. This is as follows:

$$
Y=12.527-0.226 x_{1}+0.090 x_{2}+5.073 \times 10^{-3} x_{1}{ }^{2}-1.468 \times 10^{-3} x_{2}{ }^{2}
$$

where $Y$ is the predicted butanol concentration, $x_{1}$ and $x_{2}$ are the size and loading of the carriers, respectively.

Statistical analysis using Fisher's F-test for ANOVA was carried out to gain further insights. The test showed that the model was highly significant $(p<0.0001)$ (Table 3$)$. The $p$-value for the lack-of-fit exceeded 0.05. This suggests that the model is not significant in relation to its pure error [10], indicating its reliability. The square terms of size $\left(x_{1}{ }^{2}\right)$ and loading $\left(x_{2}{ }^{2}\right)$ were also significant at $p<0.05$ (Table 3). The model's goodness-of-fit is indicated by its coefficient of determination $\left(R^{2}\right)$ [37]. In the present study, the $R^{2}$ of the correlation between the experimental and predicted results for butanol production was 0.9602 , quite close to 1.0, showing acceptable fit of the model and data. In Table 3, only the size $\left(x_{1}\right)$ of carrier had a $p$-value less than $0.05(p<0.0001)$, indicating that size of LS pieces affected butanol production.

Figure 3 shows response surface plot for the effect of size and loading of the carrier on butanol production. Increasing the carrier size resulted in a decreased $P_{B}$ value. Chang et al. [9] used sweet sorghum bagasse as an immobilized carrier for an ABE fermentation by C. acetobutylicum ABE 1201 with similar results to the current study. They explained that with increasingly larger carriers, the mass transfer in the interior of the sweet sorghum bagasse became more difficult due to increasing internal mass transfer resistance. This finally diminished the productivity of fermentation. Increasing the carrier loading to 1:31 $(w / v)$ resulted in an increased butanol concentration. Beyond these levels, the $P_{B}$ value declined. According to the analysis results, the optimal size and loading of the LS pieces were $4 \mathrm{~mm}$ and 1:31 $(w / v)$, respectively. Under this condition, the predicted butanol concentration was $13.09 \mathrm{~g} / \mathrm{L}$. 
Table 3. Analysis of variance for the parameters of RSM fitted to a quadratic response surface model.

\begin{tabular}{ccccccc}
\hline Source & Sum of Squares & $d f$ & Mean Square & F-Value & $p$-Value \\
\hline Model & 4.65 & 5 & 0.93 & 33.79 & $<0.0001$ & significant \\
$x_{1}$ : Size & 4.22 & 1 & 4.22 & 153.15 & 0.0001 \\
$x_{2}$ : Loading & $6.667 \times 10^{-3}$ & 1 & $6.667 \times 10^{-3}$ & 0.24 & 0.6377 & 0.0140 \\
$x_{1}{ }^{2}$ & 0.29 & 1 & 0.29 & 10.57 & 0.0130 \\
$x_{2}$ & 0.30 & 1 & 0.30 & & 0.8069 & not significant \\
Residual & 0.19 & 7 & 0.028 & 0.33 & & \\
Lack of Fit & 0.038 & 3 & 0.13 & & \\
Pure error & 0.15 & 4 & 0.039 & &
\end{tabular}

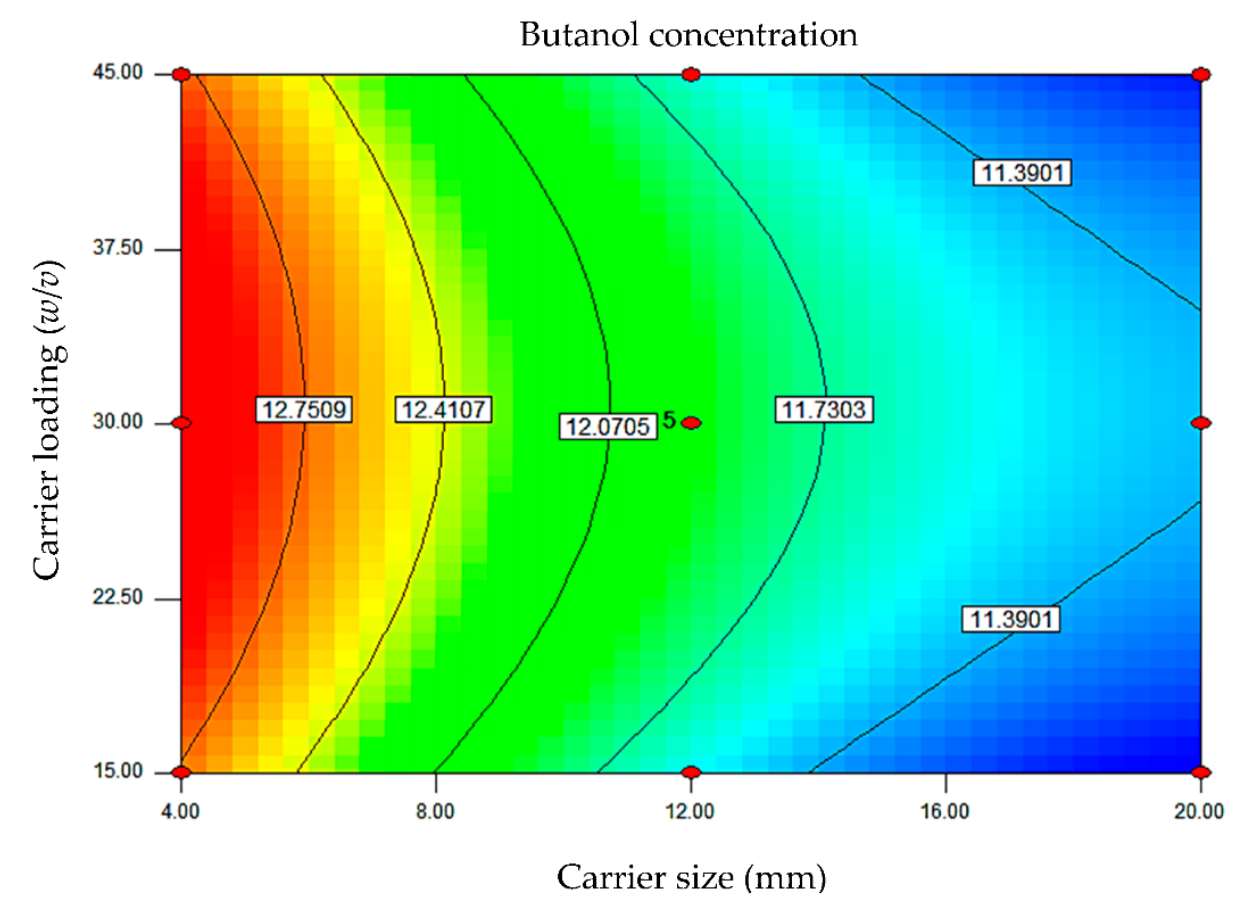

Figure 3. Response surface plot on butanol production from sugarcane molasses by the immobilized cells at various sizes and loadings of LS pieces.

To confirm the prediction, butanol fermentation by the immobilized cells under the optimum carrier size and loading of LS pieces was verified in $1 \mathrm{~L}$ screw-capped bottle. The results showed that the $P_{B}$ obtained was $12.89 \mathrm{~g} / \mathrm{L}$, which was close to the predicted value $(13.09 \mathrm{~g} / \mathrm{L})$. The results indicated that the model was acceptable. Under this condition, a $Q_{B}$ of $0.36 \mathrm{~g} / \mathrm{L} \cdot \mathrm{h}$ and $Q_{A B E}$ of $0.50 \mathrm{~g} / \mathrm{L} \cdot \mathrm{h}$ were achieved.

\subsection{Incubation Time for Cell Immobilization in Batch Butanol Fermentation}

To determine the suitable incubation time for cell immobilization on LS pieces before batch butanol fermentation, the incubation time in the immobilization medium was varied at 12,18 and $24 \mathrm{~h}$. When the immobilized cells at various incubation times were used for butanol production, the results showed that fermentation parameters measured were not obviously different. $P_{B}$ values ranged from 12.31 to $12.89 \mathrm{~g} / \mathrm{L}$ in $36 \mathrm{~h}$ (Table 4). However, to allow the bacterial cells to attach well to the LS pieces, a $24 \mathrm{~h}$ incubation time was selected for cell immobilization on LS pieces for butanol fermentation. Additionally, the results of batch butanol fermentation by immobilized cells after $24 \mathrm{~h}$ incubation showed the highest $P_{B}$ value, indicating that this condition was the most appropriate. Using immobilized cells 
for various incubation periods did not affect the metabolic pathway of butanol production because no difference in yield was observed $\left(Y_{B / S}=0.36 \mathrm{~g} / \mathrm{g}\right)$ under all conditions tested.

Table 4. Fermentation parameters of butanol fermentation from sugarcane molasses supplemented with DSY by immobilized cells of C. beijerinckii TISTR 1461 on LS pieces for various incubation times of cell immobilization in the immobilization medium.

\begin{tabular}{|c|c|c|c|}
\hline \multirow{2}{*}{ Parameter } & \multicolumn{3}{|c|}{ Incubation Time of Cell Immobilization in the Immobilization Medium } \\
\hline & $12 \mathrm{~h}$ & $18 \mathrm{~h}$ & $24 \mathrm{~h}$ \\
\hline Acetone (g/L) & $3.72 \pm 0.15^{\mathrm{a}}$ & $3.57 \pm 0.09^{a}$ & $4.08 \pm 0.11^{b}$ \\
\hline Butanol (g/L) & $12.31 \pm 0.20^{\mathrm{a}}$ & $12.46 \pm 0.11^{\mathrm{a}}$ & $12.89 \pm 0.19^{b}$ \\
\hline Ethanol (g/L) & $1.02 \pm 0.01^{\mathrm{a}}$ & $0.99 \pm 0.03^{\mathrm{a}}$ & $0.99 \pm 0.05^{\mathrm{a}}$ \\
\hline $\mathrm{ABE}(\mathrm{g} / \mathrm{L})$ & $17.05 \pm 0.35^{\mathrm{a}}$ & $17.02 \pm 0.23^{a}$ & $17.96 \pm 0.29^{b}$ \\
\hline Acetic acid (g/L) & $2.45 \pm 0.10^{\mathrm{a}}$ & $2.42 \pm 0.12^{\mathrm{a}}$ & $1.66 \pm 0.07^{b}$ \\
\hline Butyric acid (g/L) & $0.96 \pm 0.06^{\mathrm{a}}$ & $0.86 \pm 0.10^{\mathrm{a}}$ & $0.77 \pm 0.14^{\mathrm{a}}$ \\
\hline Total acid (g/L) & $3.41 \pm 0.15^{\mathrm{a}}$ & $3.28 \pm 0.21^{\mathrm{a}}$ & $2.43 \pm 0.18^{b}$ \\
\hline Sugar utilized (g/L) & $34.18 \pm 0.58^{a}$ & $34.67 \pm 0.44^{\mathrm{a}}$ & $35.32 \pm 0.39^{a}$ \\
\hline$Y_{B / S}(g / g)$ & $0.36 \pm 0.00^{\mathrm{a}}$ & $0.36 \pm 0.00^{\mathrm{a}}$ & $0.36 \pm 0.00^{\mathrm{a}}$ \\
\hline$Q_{B}(\mathrm{~g} / \mathrm{L} \cdot \mathrm{h})$ & $0.34 \pm 0.01^{\mathrm{a}}$ & $0.35 \pm 0.00^{\mathrm{ab}}$ & $0.36 \pm 0.01^{b}$ \\
\hline$Q_{A B E}(\mathrm{~g} / \mathrm{L} \cdot \mathrm{h})$ & $0.47 \pm 0.01^{\mathrm{a}}$ & $0.47 \pm 0.01^{\mathrm{a}}$ & $0.50 \pm 0.01^{b}$ \\
\hline
\end{tabular}

a,b See Table 2. $Y_{B / S}$, butanol yield; $Q_{B}$, butanol productivity and $Q_{A B E}$, ABE productivity.

\subsection{Characteristics of LS Pieces as Carriers for Cell Immobilization}

The LS pieces before and after cell immobilization for $24 \mathrm{~h}$ were observed under SEM. The results confirmed that after the immobilization process, bacterial cells were effectively attached to the surfaces and in the pores of the carriers (Figure 4). Cell attachment on surfaces by noncovalent interactions occurs through four mechanisms. These are Lifshitz-van der Waals, electrostatic and Lewis acid-base forces as well as Brownian motion [38]. Furthermore, the surface structures of LS pieces before and after cell immobilization were characterized using an AFM technique. The results are shown in Figure 5. The surfaces of LS pieces after cell immobilization (mean-square surface roughness $R_{\mathrm{ms}}=294 \mathrm{~nm}$ ) were bumpier than that before cell immobilization (mean-square surface roughness $R_{\mathrm{ms}}=286 \mathrm{~nm}$ ). SEM characterization showed that the roughness of LS pieces after cell immobilization can be attributed to the adsorption of Clostridium cells onto the carriers.
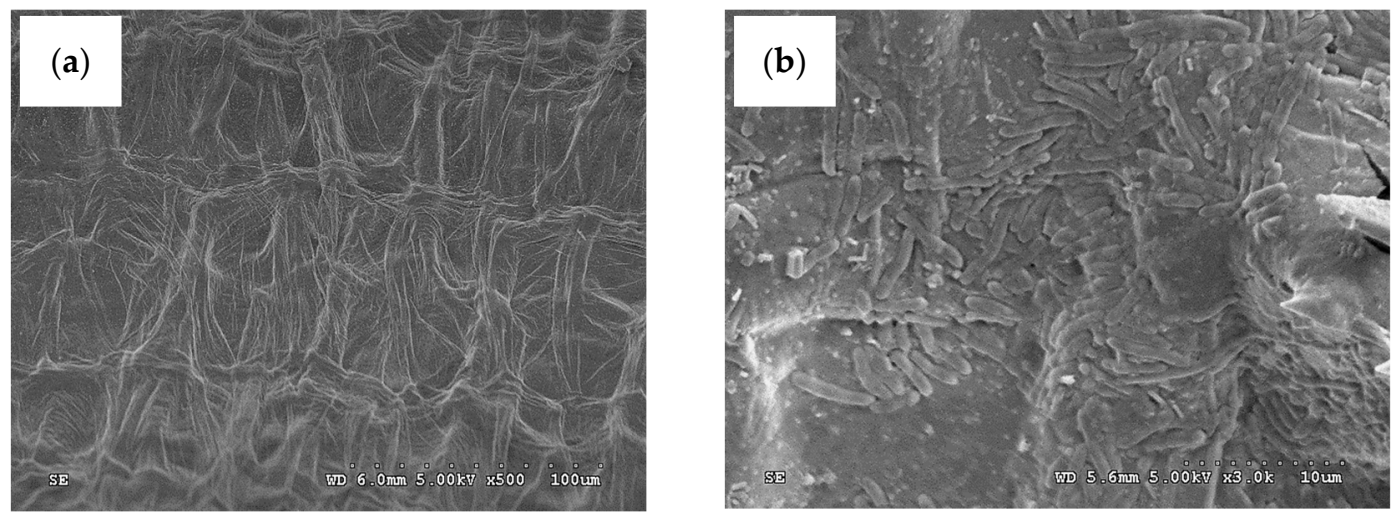

Figure 4. Scanning electron microscopic (SEM) images of LS pieces and immobilized bacterial cells on LS pieces: (a) cross view of LS before immobilization with a magnification $500 \times$ and (b) cross view of LS after immobilization for $24 \mathrm{~h}$ with a magnification of $3000 \times$. 

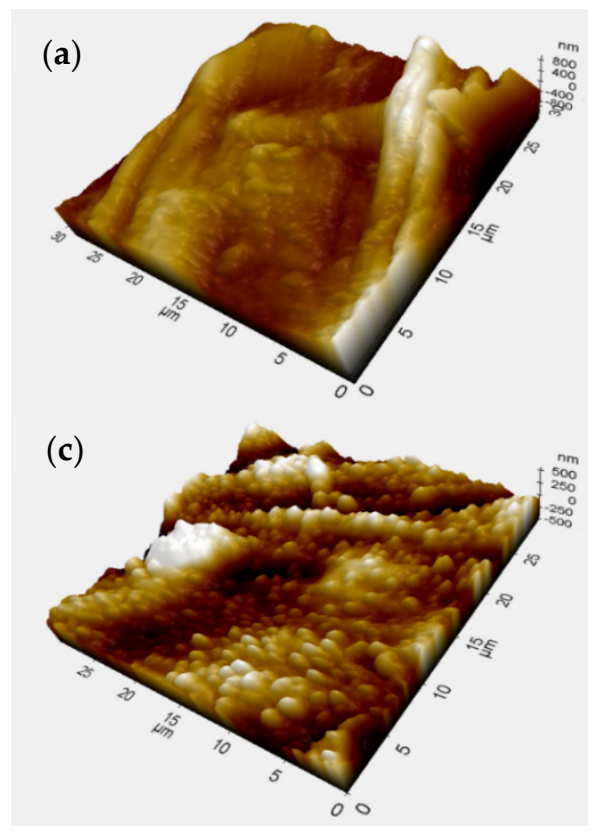
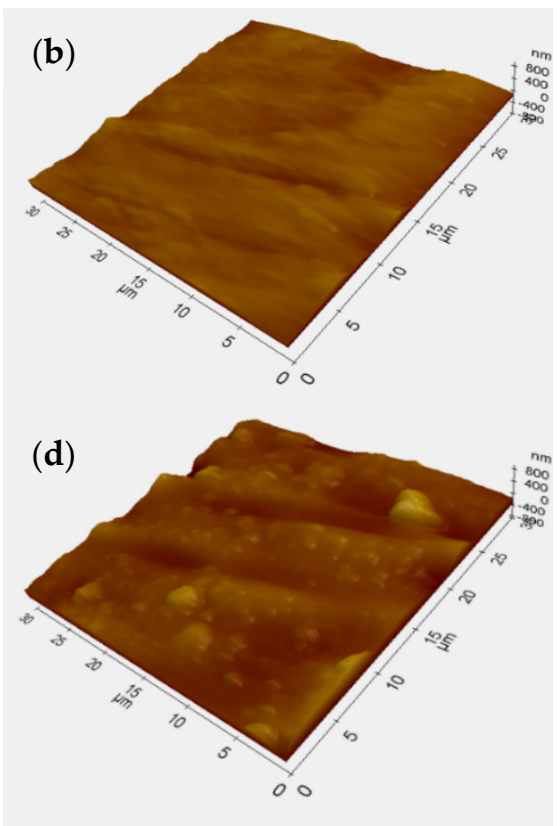

Figure 5. Atomic force microscopy (AFM) images of LS pieces before and after cell immobilization of C. beijerinckii TISTR 1461: (a) inside and (b) outside of LS before cell immobilization and (c) inside and (d) outside of LS after cell immobilization for $24 \mathrm{~h}$.

The specific surface area and total pore volume of LS pieces after cell immobilization for $24 \mathrm{~h}$ showed significant increases compared to measurements before cell immobilization (Figure 6). This indicated that $C$. beijerinckii TISTR 1461 cells occupied large volumes inside the porous carrier. The results clearly indicated that the bacterial cells were well attached to the LS carrier pieces, resulting in high specific surface area. These results are corroborated by SEM imagery (Figure 4).

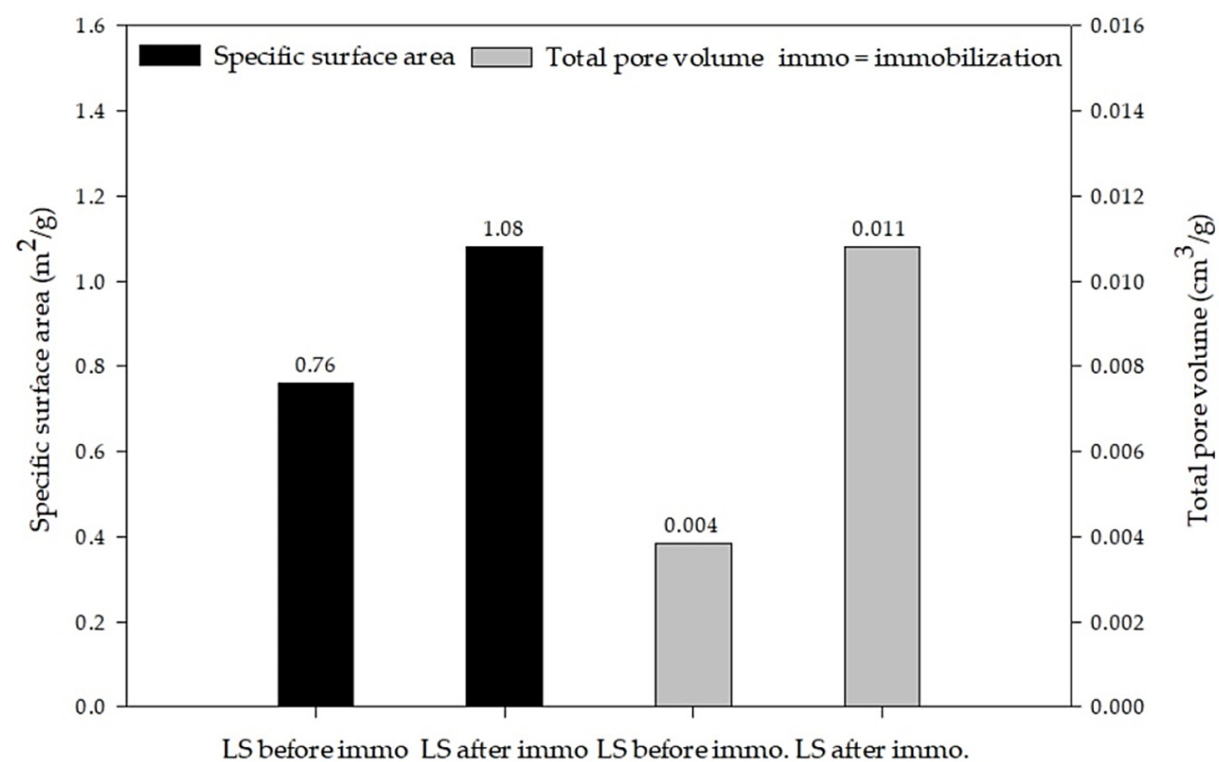

Figure 6. Specific surface area and total pore volume of LS pieces before and after cell immobilization.

To quantify the specific surface area and total pore volume of LS pieces before and after cell immobilization, a BET surface area method was employed. The specific surface area and total pore volume of LS pieces after cell immobilization for $24 \mathrm{~h}$ were $1.08 \mathrm{~m}^{2} / \mathrm{g}$ 
and $0.011 \mathrm{~cm}^{3} / \mathrm{g}$, respectively, which significant increases compared to measurements before cell immobilization $\left(0.76 \mathrm{~m}^{2} / \mathrm{g}\right.$ and $0.004 \mathrm{~cm}^{3} / \mathrm{g}$, respectively). This indicated that C. beijerinckii TISTR 1461 cells occupied large volumes inside the porous carrier. The results clearly indicated that the bacterial cells were well attached to the LS carrier pieces, resulting in high specific surface area. These results are corroborated by SEM imagery (Figure 4).

\subsection{Butanol Production in Various Bioreactors}

The optimum carrier size and carrier loading for cell immobilization to produce butanol was obtained using $1 \mathrm{~L}$ screw-capped bottles with $P_{B}, 12.89 \mathrm{~g} / \mathrm{L}, Q_{B}, 0.36 \mathrm{~g} / \mathrm{L} \cdot \mathrm{h}$ and $Q_{A B E}, 0.50 \mathrm{~g} / \mathrm{L} \cdot \mathrm{h}$ (Table 5). In the current study, the butanol fermentation was carried out in various bioreactors-i.e., STR, CR and CR coupled with an STR, to determine if the immobilized cells could effectively produce butanol in these reactors. The butanol fermentation profiles using immobilized cells in all reactors were similar (Figure 7). The $P_{B}$ using an STR was not significantly different from that using screw-capped bottles, indicating that the LS pieces can shield the cells from shear forces under impeller agitation. In the CR, the $P_{B}$ produced was $25 \%$ lower than those in screw-capped bottles and the STR. This might have been due to poor mixing in the bubble column bioreactor causing heat and mass transfer limitations [17]. A lot of gas bubbles $\left(\mathrm{H}_{2}\right.$ and $\left.\mathrm{CO}_{2}\right)$ were created during 12 to $24 \mathrm{~h}$ of the fermentation, which made them a better transport medium. However, after $24 \mathrm{~h}$, fewer gas bubbles were observed, resulting in poorer mixing in the CR. Problems with mixing in a bubble column may arise from liquid back mixing [39-41]. The liquid flow patterns in a bubble column are normally imperfect. The liquid flow is churning and turbulent or a slug flow depending on the gas flow rate. Additionally, mixing in the CR may be blocked by the LS carriers used in this study. In the screw-capped bottles and STR, a magnetic bar and impellers were, respectively, used for agitation, thereby attaining good mixing.

Table 5. Butanol production from sugarcane molasses by immobilized C. beijerinckii TISTR 1461 cells on LS pieces using various bioreactors at $36 \mathrm{~h}$ of fermentation.

\begin{tabular}{|c|c|c|c|c|}
\hline Parameter & Screw-Capped Bottles & STR & CR & CR with STR \\
\hline Butanol (g/L) & $12.89 \pm 0.19^{\mathrm{a}}$ & $12.17 \pm 0.36^{\mathrm{a}}$ & $9.12 \pm 0.37^{b}$ & $5.43 \pm 0.66^{c}$ \\
\hline $\mathrm{ABE}(\mathrm{g} / \mathrm{L})$ & $17.96 \pm 0.29^{a}$ & $17.01 \pm 0.62^{\mathrm{a}}$ & $12.99 \pm 0.34^{b}$ & $12.97 \pm 0.57^{b}$ \\
\hline Total acid (g/L) & $2.43 \pm 0.18^{\mathrm{a}}$ & $3.26 \pm 0.31^{\mathrm{b}}$ & $2.07 \pm 0.19^{\mathrm{a}}$ & $2.25 \pm 0.22^{\mathrm{a}}$ \\
\hline Sugar utilized (g/L) & $35.32 \pm 0.39^{a}$ & $33.78 \pm 0.41^{\mathrm{a}}$ & $31.64 \pm 0.46^{b}$ & $32.01 \pm 0.53^{b}$ \\
\hline$Y_{B / S}(g / g)$ & $0.36 \pm 0.00^{\mathrm{a}}$ & $0.36 \pm 0.01^{\mathrm{a}}$ & $0.29 \pm 0.01^{b}$ & $0.17 \pm 0.02^{c}$ \\
\hline$Q_{B}(\mathrm{~g} / \mathrm{L} \cdot \mathrm{h})$ & $0.36 \pm 0.01^{\mathrm{a}}$ & $0.34 \pm 0.01^{\mathrm{a}}$ & $0.25 \pm 0.01^{\mathrm{b}}$ & $0.15 \pm 0.02^{\mathrm{c}}$ \\
\hline$Q_{A B E}(\mathrm{~g} / \mathrm{L} \cdot \mathrm{h})$ & $0.50 \pm 0.01^{\mathrm{a}}$ & $0.47 \pm 0.02^{\mathrm{a}}$ & $0.36 \pm 0.03^{b}$ & $0.36 \pm 0.04^{b}$ \\
\hline
\end{tabular}

Due to the advantages and disadvantages of STR and CR described above, a CR coupled with an STR was constructed for butanol production (Figure 1b). This combination of a CR (containing the carriers) and STR (containing the fermentation broth) may improve butanol production through cell immobilization. During fermentation, the medium was circulated between the CR and STR in a loop. Therefore, main microbial activity in the CR was due to the immobilized cells on the carriers, whereas in the STR, the microbial activity was by the free cells of $C$. beijerinckii TISTR 1461 detached from the CR. Medium circulation between the reactors might improve mixing and this would reduce mass/heat transfer limitations occurring in a system with only a CR. However, in the CR coupled with an STR, it was found that the $P_{B}$ value was $\sim 3.7 \mathrm{~g} / \mathrm{L}$ lower than when using only the $\mathrm{CR}$, and the value was only $45 \%$ of that using the STR alone. These results indicate that the system using a CR coupled with an STR under the conditions tested was not suitable for butanol production and/or could not solve the problems of heat and mass transfer limitations.

Additionally, the $Y_{B / S}$ values using various bioreactors were different. The highest $Y_{B / S}$ was obtained in screw-capped bottles and the STR, followed by using a CR and a CR coupled with an STR, respectively. This implies that the metabolic pathway of butanol 
production changed, which might have been due to poorer mixing during the fermentation. Wechgama et al. [7] studied butanol production from sugarcane molasses by C. beijerinckii TISTR 1461 in a bioreactor with and without agitation. They found that the $P_{A B E}$ value under agitation was higher than under a static condition, and the $Q_{B}$ value under agitation increased by approximately $30 \%$ compared to static conditions with no agitation.

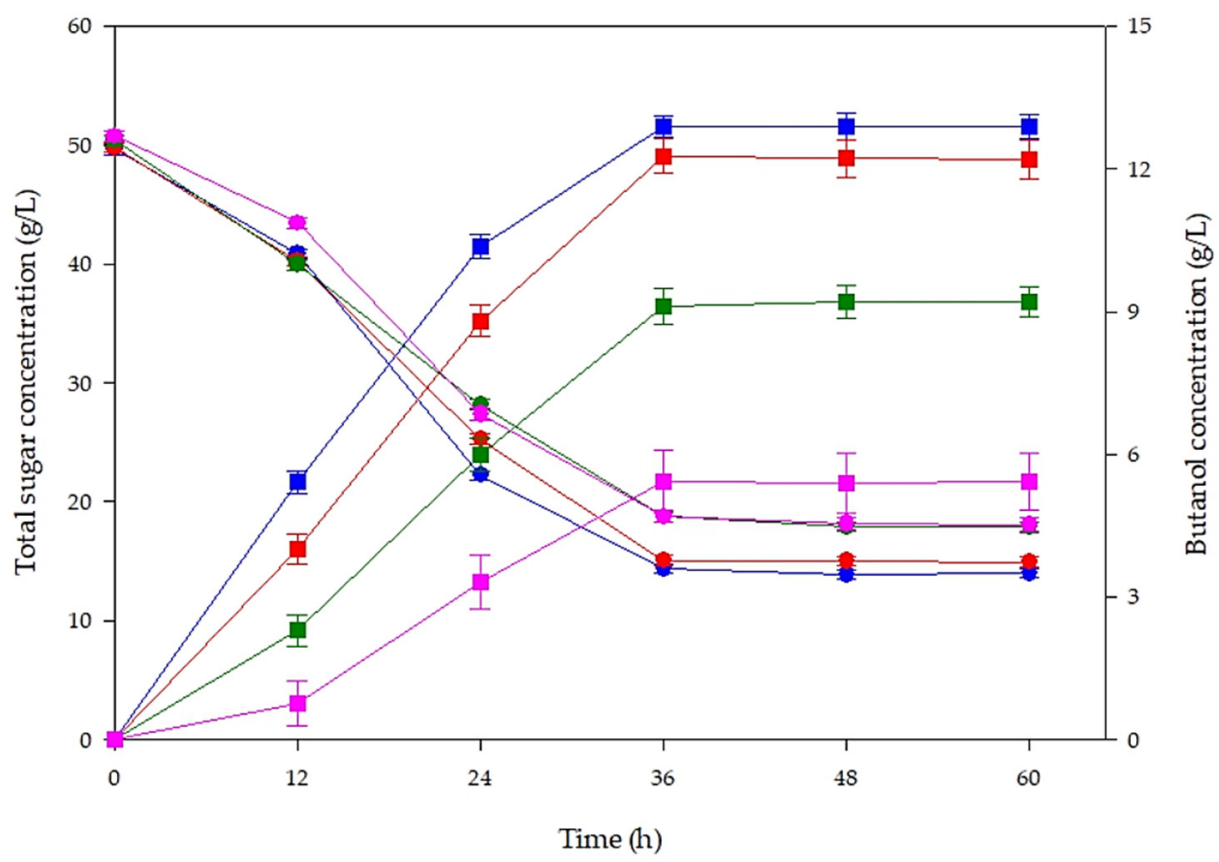

Figure 7. Butanol production profiles from sugarcane molasses by the immobilized cells on LS pieces using screw-capped bottles (blue lines), STR (red lines), CR (green lines) and CR with STR (pink lines): total sugar $(\bullet)$ and butanol

The results obtained from the current study indicate that the STR was a suitable reactor for butanol fermentation using immobilized cells, whereas the CR and CR coupled with an STR were unsuitable. Appropriate conditions for the operation of the CR and a CR coupled with an STR may improve the fermentation efficiency. Moreover, an in situ product recovery using a gas stripping system may enhance butanol production by reducing butanol toxicity in the broth during the $\mathrm{ABE}$ fermentation $[7,8]$. This technique is under investigation. The high $P_{B}$ value obtained by immobilized cells on LS pieces using an STR also indicated that LS, a low-cost carrier, could resist the high shear occurring in an STR to a greater degree than synthetic carriers such as calcium alginate.

Comparison of butanol production by immobilized cells with other studies is summarized in Table 6 . The observed $P_{B}$ values are in the range of 6-15 g/L. The highest $P_{B}$ was obtained from sugarcane juice at an initial sugar concentration of $80 \mathrm{~g} / \mathrm{L}$ by immobilized Clostridium cells on thin-shell silk cocoons. In our work, the $P_{B}(12.89 \mathrm{~g} / \mathrm{L})$ from sugarcane molasses by immobilized C. beijerinckii TISTR 1461 cells on LS pieces was about $2 \mathrm{~g} / \mathrm{L}$ lower than the highest $P_{B}$ reported $(15.00 \mathrm{~g} / \mathrm{L})$. This was due to lower initial sugar concentration used in our study $(50 \mathrm{~g} / \mathrm{L})$. However, the highest butanol productivity $\left(Q_{B}\right)$ of $0.36 \mathrm{~g} / \mathrm{L} \cdot \mathrm{h}$ was seen in the current work, which was approximately 1.5 to 3.3 times higher than in other studies. These varying results indicate that there are many factors influencing butanol concentration and productivity of a butanol fermentation by immobilized cells. Such influential factors may include a variety of substrates and initial sugar concentrations, Clostridium strains, immobilization carriers, environmental conditions and modes of fermentation. 
Table 6. Comparison of butanol production under various conditions.

\begin{tabular}{|c|c|c|c|c|c|c|}
\hline $\begin{array}{c}\text { Substrate } \\
\text { (Initial Sugar } \\
\text { Concentration) }\end{array}$ & Strain & $\begin{array}{c}\text { Immobilization } \\
\text { Carrier }\end{array}$ & Reactor & $\begin{array}{c}P_{B} \\
(\mathrm{~g} / \mathrm{L})\end{array}$ & $\begin{array}{c}Q_{B} \\
(\mathrm{~g} / \mathrm{L} \cdot \mathrm{h})\end{array}$ & References \\
\hline $\begin{array}{c}\text { Xylose } \\
(54 \mathrm{~g} / \mathrm{L})\end{array}$ & C. acetobutylicum ATCC 824 & Corn stover & $100 \mathrm{~mL}$ serum bottle & 8.44 & 0.12 & [42] \\
\hline $\begin{array}{l}\text { Glucose } \\
(60 \mathrm{~g} / \mathrm{L})\end{array}$ & C. acetobutylicum ABE 1201 & $\begin{array}{l}\text { Sweet sorghum } \\
\text { bagasse }\end{array}$ & $1 \mathrm{~L}$ fermenter & 14.02 & 0.14 & [6] \\
\hline $\begin{array}{l}\text { Glucose } \\
(60 \mathrm{~g} / \mathrm{L})\end{array}$ & C. beijerinckii TISTR 1461 & Bricks & $250 \mathrm{~mL}$ baffled flask & 5.80 & 0.12 & [10] \\
\hline $\begin{array}{l}\text { Sugarcane juice } \\
(80 \mathrm{~g} / \mathrm{L})\end{array}$ & C. acetobutylicum ATCC 824 & $\begin{array}{l}\text { Thin-shell silk } \\
\text { cocoons }\end{array}$ & $1 \mathrm{~L}$ fermenter & 15.00 & 0.11 & [35] \\
\hline $\begin{array}{l}\text { Corn stalk juice } \\
\qquad(60 \mathrm{~g} / \mathrm{L})\end{array}$ & C. acetobutylicum ABE 1201 & $\begin{array}{l}\text { Corn stalk } \\
\text { bagasse }\end{array}$ & $1 \mathrm{~L}$ fermenter & 14.00 & 0.19 & [43] \\
\hline $\begin{array}{l}\text { Corn stalk juice } \\
\qquad(63 \mathrm{~g} / \mathrm{L})\end{array}$ & C. acetobutylicum ABE 1201 & $\begin{array}{l}\text { Pretreated corn } \\
\text { stalk bagasse }\end{array}$ & $250 \mathrm{~mL}$ serum bottle & 14.28 & 0.25 & [12] \\
\hline $\begin{array}{l}\text { Glucose } \\
(30 \mathrm{~g} / \mathrm{L})\end{array}$ & C. acetobutylicum CICC 8012 & Bagasse & $100 \mathrm{~mL}$ conical flask & 5.80 & 0.18 & [33] \\
\hline $\begin{array}{l}\text { Sugarcane } \\
\text { molasses } \\
(50 \mathrm{~g} / \mathrm{L})\end{array}$ & C. beijerinckii TISTR 1461 & Lotus stalks & $\begin{array}{c}1 \text { L screw-capped } \\
\text { bottle } \\
2 \text { L fermenter }\end{array}$ & $\begin{array}{l}12.89 \\
12.17\end{array}$ & $\begin{array}{l}0.36 \\
0.34\end{array}$ & Current study \\
\hline
\end{tabular}

$P_{B}$, butanol concentration and $Q_{B}$, butanol productivity.

\section{Conclusions}

The immobilized cells of $C$. beijerinckii TISTR 1461 can be effectively used to promote butanol production from sugarcane molasses. Diluted sugarcane molasses (initially $50 \mathrm{~g} / \mathrm{L}$ of sugar) supplemented with only $1 \mathrm{~g} / \mathrm{L}$ of yeast extract is an appropriate medium for cell immobilization of $C$. beijerinckii TISTR 1461, and LS pieces are a suitable low-cost supporting material for cell immobilization to produce butanol. The C. beijerinckii TISTR 1461 cells were effectively attached to the surfaces and the pores of the LS pieces within $24 \mathrm{~h}$ in an immobilization process. This was confirmed through examination of SEM and AFM imagery. At the optimal size $(4 \mathrm{~mm})$ and loading $(1: 31 \mathrm{w} / \mathrm{v})$ of LS pieces, immobilized cells produced a high butanol concentration $\left(P_{B}, 12.89 \mathrm{~g} / \mathrm{L}\right)$, productivity $\left(Q_{B}, 0.36 \mathrm{~g} / \mathrm{L} \cdot \mathrm{h}\right)$ and yield $\left(Y_{B / S}, 0.36 \mathrm{~g} / \mathrm{g}\right)$. These values were $~ 13 \%$ to $29 \%$ higher than those using free cells. Additionally, immobilized cells on LS pieces could be successfully used for butanol fermentation in an STR. A CR can also be employed yielding a $P_{B}$ value that is $25 \%$ lower than that using an STR.

Author Contributions: Conceptualization, P.L. and L.L.; methodology and formal analysis, P.N.; investigation and writing—original draft preparation, P.N.; writing—review and editing, P.L., L.L. and P.N.; Supervision, P.L. All authors have read and agreed to the published version of the manuscript.

Funding: This research was funded by the Thailand Research Fund (TRF) through the Royal Golden Jubilee (RGJ) Ph.D. Program (Grant Number PHD/0092/2559) and the National Research Council of Thailand (NRTC), Thailand.

Institutional Review Board Statement: Not applicable.

Informed Consent Statement: Not applicable.

Acknowledgments: The authors would like to thank Mitr Phu Viang Sugar Co., Ltd., Khon Kaen, Thailand, and Beer Thip Brewery Co., Ltd., Phra Nakhon Si Ayutthaya, Thailand, for supplying sugarcane molasses and dried spent yeast, respectively.

Conflicts of Interest: The authors declare no conflict of interest.

\section{References}

1. Lee, S.Y.; Park, J.H.; Jang, S.H.; Nielsen, L.K.; Kim, J.; Jung, K.S. Fermentative butanol production by clostridia. Biotechnol. Bioeng. 2008, 101, 209-227. [CrossRef]

2. Qureshi, N.; Ezeji, T.C. Butanol, 'a superior biofuel' production from agricultural residues (renewable biomass): Recent progress in technology. Biofuel Bioprod. Biorefin. 2008, 2, 319-330. [CrossRef] 
3. ButaNext. Next Generation Biobutanol. Available online: https://ec.europa.eu/inea/en/horizon-2020/projects/h2020-energy / biofuels/butanext (accessed on 12 May 2020).

4. Ezeji, T.C.; Qureshi, N.; Blaschek, H.P. Production of acetone butanol (AB) from liquefied corn starch, a commercial substrate, using Clostridium beijerinckii coupled with product recovery by gas stripping. J. Ind. Microbiol. Biotechnol. 2007, 34, 771-777. [CrossRef]

5. Ezeji, T.C.; Milne, C.; Price, N.D.; Blaschek, H.P. Achievements and perspectives to overcome the poor solvent resistance in acetone and butanol-producing microorganisms. Appl. Microbiol. Biotechnol. 2010, 85, 1697-1712. [CrossRef]

6. Cai, D.; Li, P.; Chen, C.; Wang, Y.; Hu, S.; Cui, C.; Qin, P.; Tan, T. Effect of chemical pretreatments on corn stalk bagasse as immobilizing carrier of Clostridium acetobutylicum in the performance of a fermentation-pervaporation coupled system. Bioresour. Technol. 2016, 220, 68-75. [CrossRef]

7. Wechgama, K.; Laopaiboon, L.; Laopaiboon, P. Enhancement of batch butanol production from sugarcane molasses using nitrogen supplementation integrated with gas stripping for product recovery. Ind. Crop. Prod. 2017, 95, 216-226. [CrossRef]

8. Thanapornsin, T.; Sanchanda, P.; Laopaiboon, L.; Laopaiboon, P. Batch butanol fermentation from sugarcane molasses integrated with a gas stripping system: Effects of sparger types and gas flow rates. Asia Pac. J. Sci. Technol. 2018, 23, 1-12. [CrossRef]

9. Chang, Z.; Cai, D.; Wang, C.; Li, L.; Han, J.; Qin, P.; Wang, Z. Sweet sorghum bagasse as an immobilized carrier for ABE fermentation by using Clostridium acetobutylicum ABE 1201. RSC Adv. 2014, 4, 21819-21825. [CrossRef]

10. Chen, Y.; Zhou, T.; Liu, D.; Li, A.; Xu, S.; Liu, Q. Production of butanol from glucose and xylose with immobilized cells of Clostridium acetobutylicum. Biotechnol. Bioprocess Eng. 2013, 18, 234-241. [CrossRef]

11. Djukic-Vukovic, A.P.; Mojovic, L.V.; Jokic, B.M.; Nikolic, S.B.; Pejin, J.D. Lactic acid production on liquid distillery stillage by Lactobacillus rhamnosus immobilized onto zeolite. Bioresour. Technol. 2013, 135, 454-458. [CrossRef]

12. Yen, H.W.; Li, R.J.; Ma, T.W. The development process for a continuous acetone-butanol-ethanol (ABE) fermentation by immobilized Clostridium acetobutylicum. J. Taiwan Inst. Chem. Eng. 2011, 42, 902-907. [CrossRef]

13. Vichuviwat, R.; Boonsombuti, A.; Luengnaruemitchai, A.; Wongkasemjit, S. Enhanced butanol production by immobilized Clostridium beijerinckii TISTR 1461 using zeolite 13X as a carrier. Bioresour. Technol. 2014, 172, 76-82. [CrossRef]

14. Survase, S.A.; Heiningen, A.V.; Granström, T. Continuous bio-catalytic conversion of sugar mixture to acetone-butanol-ethanol by immobilized Clostridium acetobutylicum DSM 792. Appl. Microbiol. Biotechnol. 2012, 93, 2309-2316. [CrossRef] [PubMed]

15. Cai, D.; Chang, Z.; Gao, L.; Chen, C.; Niu, Y.; Qin, P.; Wang, Z.; Tan, T. Acetone-butanol-ethanol (ABE) fermentation integrated with simplified gas stripping using sweet sorghum bagasse as immobilized carrier. Chem. Eng. J. 2015, 277, 176-185. [CrossRef]

16. Lestinsky, P.; Vayrynen, P.; Vecer, M.; Wichterle, K. Hydrodynamics of airlift reactor with internal circulation loop: Experiment vs. CFD simulation. Procedia Eng. 2012, 42, 892-907. [CrossRef]

17. Kantarci, N.; Borak, F.; Ulgen, K.O. Bubble column reactors. Process Biochem. 2005, 40, 2263-2283. [CrossRef]

18. Office of the Cane and Sugar Board. Status of Sugarcane and Sugar in Thailand 2020. Available online: http://www.ocsb.go.th/ th/cms / detail.php?ID=11344\&SystemModuleKey=production (accessed on 1 June 2020).

19. Li, W.; Cheng, C.; Cao, G.; Ren, N. Enhanced biohydrogen production from sugarcane molasses by adding Ginkgo biloba leaves. Bioresour. Technol. 2020, 298, 122523. [CrossRef]

20. Sun, Y.; Xu, Z.; Zheng, Y.; Zhou, J.; Xiu, Z. Efficient production of lactic acid from sugarcane molasses by a newly microbial consortium CEE-DL15. Process Biochem. 2019, 81, 132-138. [CrossRef]

21. Cazetta, M.; Celligoi, M.; Buzato, J.; Scarmino, I.; Da Silva, R. Optimization study for sorbitol production by Zymomonas mobilis in sugarcane molasses. Process Biochem. 2005, 40, 747-751. [CrossRef]

22. Ahmed, A.; Farag, S.S.; Hassan, I.A.; Botros, H.W. Production of gluconic acid by using some irradiated microorganisms. J. Radiat. Res. Appl. Sci. 2015, 8, 374-380. [CrossRef]

23. Cao, W.; Wang, Y.; Luo, J.; Yin, J.; Xing, J.; Wan, Y. Succinic acid biosynthesis from cane molasses under low pH by Actinobacillus succinogenes immobilized in luffa sponge matrices. Bioresour. Technol. 2018, 268, 45-51. [CrossRef] [PubMed]

24. Xu, S.; Hao, N.; Xu, L.; Liu, Z.; Yan, M.; Li, Y.; Ouyang, P. Series fermentation production of ornithine and succinic acid from cane molasses by Corynebacterium glutamicum. Biochem. Eng. J. 2015, 99, 177-182. [CrossRef]

25. Li, H.G.; Luo, W.; Gu, Q.Y.; Wang, Q.; Hu, W.J.; Yu, X.B. Acetone, butanol, and ethanol production from cane molasses using Clostridium beijerinckii mutant obtained by combined low-energy ion beam implantation and N-methyl- $N$-nitro- $N$ nitrosoguanidine induction. Bioresour. Technol. 2013, 137, 254-260. [CrossRef]

26. Narueworanon, P.; Phukoetphim, N.; Laopaiboon, L.; Laopaiboon, P. Impacts of initial sugar, nitrogen and calcium carbonate on butanol fermentation from sugarcane molasses by Clostridium beijerinckii. Energies 2020, 13, 694. [CrossRef]

27. Sirisantimethakom, L.; Laopaiboon, L.; Sanchanda, P.; Chatleudmongkol, J.; Laopaiboon, P. Improvement of butanol production from sweet sorghum juice by Clostridium beijerinckii using an orthogonal array design. Ind. Crop. Prod. 2016, 79, 287-294. [CrossRef]

28. Qureshi, N.; Blaschek, H.P. Butanol recovery from model solution/fermentation broth by pervaporation: Evaluation of membrane performance. Biomass Bioenergy 1999, 17, 175-184. [CrossRef]

29. Ariyajaroenwong, P.; Laopaiboon, P.; Laopaiboon, L. Capability of sweet sorghum stalks as supporting materials for yeast immobilization to produce ethanol under various fermentation processes. J. Taiwan Inst. Chem. Eng. 2015, 49, 79-84. [CrossRef]

30. Loyarkat, S.; Cheirsilp, B.; Prasertsan, P. Two-stage repeated-batch fermentation of immobilized Clostridium beijerinckii on oil palm fronds for solvents production. Process Biochem. 2015, 50, 1167-1176. [CrossRef] 
31. Bai, F.; Lu, W.Q. Enhanced heat transfer analysis of latent functionally thermal fluid. Heat Tran. Asian Res. 2004, 33, 383-392. [CrossRef]

32. Mecozzi, M. Estimation of total carbohydrate amount in environmental samples by the phenol-sulphuric acid method assisted by multivariate calibration. Chemom. Intell. Lab. Syst. 2005, 79, 84-90. [CrossRef]

33. Al-Shorgani, N.K.N.; Kalil, M.S.; Yusoff, W.M.W.; Hamid, A.A. Impact of $\mathrm{pH}$ and butyric acid on butanol production during batch fermentation using a new local isolate of Clostridium acetobutylicum YM1. Saudi J. Biol. Sci. 2018, 25, 339-348. [CrossRef] [PubMed]

34. Zhou, W.; Liu, J.; Fan, S.; Xiao, Z.; Qiu, B.; Wang, Y.; Li, J.; Liu, Y. Biofilm immobilization of Clostridium acetobutylicum on particulate carriers for acetone-butanol-ethanol (ABE) production. Bioresour. Technol. Rep. 2018, 3, 211-217. [CrossRef]

35. He, Q.; Chen, H. Improved efficiency of butanol production by absorbed lignocellulose fermentation. J. Biosci. Bioeng. 2013, 115, 298-302. [CrossRef] [PubMed]

36. Kittithanesuan, N.; Phisalaphong, M. Enhanced acetone-butanol production from sugarcane juice by immobilized Clostridium acetobutylicum (ATCC 824) on thin-shell silk cocoons. Biotechnol. Bioprocess Eng. 2015, 20, 599-607. [CrossRef]

37. Jangchud, A. Product optimization. In Statistics for Product Development and Application; Kasetsart University: Bangkok, Thailand, 2006; pp. 241-288.

38. Bos, R.; Van Der Mei, H.C.; Busscher, H.J. Physico-chemistry of initial microbial adhesive interactions-its mechanisms and methods for study. FEMS Microbiol. Rev. 1999, 23, 179-230. [CrossRef]

39. Alvaré, J.; Al-Dahhan, M.H. Liquid phase mixing in trayed bubble column reactors. Chem. Eng. Sci. 2006, 61, 1819-1835. [CrossRef]

40. Kantak, M.V.; Shetty, S.A.; Kelkar, B.G. Liquid phase back mixing in bubble column reactors-a new correlation. Chem. Eng. Commun. 1994, 127, 23-34. [CrossRef]

41. Yang, Y.B.; Devanathan, N.; Duduković, M.P. Liquid back mixing in bubble columns. Chem. Eng. Sci. 1992, 47, $2859-2864$. [CrossRef]

42. He, C.R.; Lee, M.C.; Kuo, Y.Y.; Wu, T.M.; Li, S.Y. The influence of support structures on cell immobilization and acetone-butanolethanol (ABE) fermentation performance. J. Taiwan Inst. Chem. Eng. 2017, 78, 27-31. [CrossRef]

43. Chang, Z.; Cai, D.; Wang, Y.; Chen, C.; Fu, C.; Wang, G.; Qin, P.; Wang, Z.; Tan, T. Effective multiple stages continuous acetonebutanol-ethanol fermentation by immobilized bioreactors: Making full use of fresh corn stalk. Bioresour. Technol. 2016, 205, 82-89. [CrossRef] [PubMed] 